\title{
The Question of God and the Quest for God: Hans Jonas, Plato, and Beyond...
}

DOI: $10.14746 /$ pea. 2020.1 .8

EMIDIO SPINELLI / Sapienza Università di Roma /

1. Hans Jonas was a thinker wholly immersed in the "Short Twentieth Century": ${ }^{\text {that }}$ difficult or even tragic "Age of Extremes" - at least for a man like him, a Jew fleeing from the horrors of his home country Germany, when it was under the sway of Nazi folly. It is an age that continues to represent an inevitable point of reference for many crucial reflections in contemporary philosophical debate. As a useful opening remark, with regard to Jonas's education, it is worth recalling what Frau Lore Jonas vividly recalls in her Geleitwort to the Erinnerungen, the autobiographical book that best brings out his personality and intellectual standing:

\footnotetext{
${ }^{1}$ On this label see Hobsbawn (1994).
} 
Er Besaß jene große humanistische Bildung, die seiner Generation eigen war und die jetzt allmählich verschwindet. Er konnte Homer auf griechisch und Cicero auf lateinisch zitieren, lernte als Oberschüler Hebräisch, und die Propheten waren ihm lieb (Jonas 2003: 7).

It seems undeniable, therefore, that in reconstructing the conceptual universe of Jonas's oeuvre a privileged place can, or indeed must, be reserved for his relationship with the Classical heritage. Certainly, it is far from easy to provide a clear and detailed outline of this relationship with the ancient philosophical past. Jonas is not the kind of author who peppers his writing with quotes, references, and footnotes. Often his engagement with such a past is a silent one, and only a painstaking approach can reveal the presence of this or that ancient author. In the light of this premise, I believe it may be possible to identify some philosophers and themes particularly dear to Jonas, the first being, in our case, Plato and his approach to myths.

2. The powerful and openly asserted presence of Plato emerges in a more or less explicit way in many of Jonas's publications - and it is often substantiated by references to his fundamental dialogues (the Apology, Crito, Euthyphro, Gorgias, Theaetetus, Sophist, Phaedo, Meno, Symposium, and Republic, not to mention the crucial role assigned to the Timaeus, as we shall see in a moment). At the same time, this presence is supported by a historical perspective and by an explicit theoretical requirement. It may be added that in several texts Jonas constructs his own philosophy, a new and original one, also by establishing a sophisticated dialectical relationship with Platonic thought, characterised by a continuity imbued with esteem and a discontinuity imbued with independence.

Some of the great themes and "unavoidable questions" with respect to which Jonas establishes this fruitful relationship and close engagement are worth recalling, if only succinctly. They include: an evaluation of the very particular brand of dualism championed by Plato, freed from the exegetical assumption that had erroneously sought to turn it into the source of the later "Gnostic syndrome"; ${ }^{2}$ the new view of nature expounded in the contributions brought together in The Phenomenon of Life; ${ }^{3}$ the political insights far removed from any form of utopia, including the Platonic one - that emerge from Das Prinzip Verantwortung (see esp. Jonas 2015: 335-420); and our specific topic here, namely the highly original use made in Der Gottesbegriff nach Auschwitz of the Platonic heritage, associated with the mythical figure of the Demiurge in the Timaeus (see infra, $\$ \$ S$ 4-6)

The figure of Plato also represents a constant point of reference in Jonas's teaching, for instance in the lecture courses he held in Canada and later at the "New School for Social Research" in New York. Here I cannot illustrate the content of all these courses - many of which remain unpublished and also touch upon other aspects of ancient

2 His conclusions are also based on a sophisticated reinterpretation of "Plato's language": see Jonas (1934: 251-254).

3 See in particular the essay The Practical Uses of Theory (Jonas 1966: 188-210). 
thought, such as pre-Socratic philosophy. ${ }^{4}$ I shall only recall three courses, which in my view provide a good picture of Jonas's varied approach to the Platonic corpus. It may be useful, first of all, to mention the succinct, almost textbook reconstruction offered by Jonas in a course entitled Term Notes for Philosophy no. 111. History of Philosophy: Plato, Aristotle and the Later Schools (1963: HJ 20-11-4, as yet unpublished). Here the most salient aspects of key Platonic doctrines are analysed from a historical perspective in an effort to provide as comprehensive an account as possible. In contrast, a staunch and radical theoretical approach to Platonic thought is the hallmark of another course, devoted to Major Systems of Philosophy (this too dates from 1963, but has now been published: see Jonas 2012). Jonas adopts a highly significant theoretical category, that of "system", to bring together different views that are remote from one another both chronologically and in terms of their defining hermeneutical structures. He does so without making any claim to be tracing a progressive development of such views or one based on their steady accumulation. Within such a context, Jonas invokes Plato as one of the leading characters of a much bigger story. His philosophy appears to be resting on "basic convictions" that are crucial in order to trace a powerful profile of his original thought, which brings out an undeniable, underlying systematicity. ${ }^{5}$ This reinterpretation becomes a genuine close-quarter engagement with one of Jonas's most beloved and most oft-quoted texts, the Timaeus, in another course, entitled Theories of Time (Jonas 1971: HJ 3-6-1/3-6-9, as yet unpublished). The first part of this course might be described as a running commentary on the dialogue, offering some acute reflections on basic notions such as those of cosmos, time, and eternity.

Until his last works at any rate, Jonas, while presenting his new doctrine of being, openly acknowledges his indebtedness to the great thinkers of the past (Spinoza, Leibniz, Hegel, and especially Plato): "in ihre Schule, durch ihre Schule müssen wir gehen, und das Fragen zu lernen, von ihrem Siegen und Versagen uns belehren lassen”. 6

3. Even more specifically, this short contribution will focus on a single moment in the encounter - or, rather, intellectual relationship - between Hans Jonas and Plato, against the backdrop of an unquestionable esteem for the Greek philosopher and, at the same time, a desire to move beyond his philosophy, which reflects a degree of critical autonomy. For Jonas, Plato represents (in terms of continuity as much as of opposition) the cornerstone of key traditions in ancient philosophy, but also the source with which the whole Western intellectual tradition had to engage. Besides, in a hyperbolic (and perhaps questionable) way (see in this regard Chiaradonna, 2017: 27-28), à la Whitehead, this

4 See at least Philosophy and The first Epoque of Greek Philosophy (HJ 19-6-2, from his time in Canada); and History of Philosophy I: The Presocratics (Jonas 1962-1963: HJ 2-14-1-15).

${ }^{5}$ For more details about Jonas's interpretation of Plato in these lectures, see Spinelli (2019; esp. ch. III-IV).

${ }^{6}$ As we read in the essay Materie, Geist und Schöpfung. Kosmologischer Befund und kosmogonische Vermutung (Jonas 2014: 282). 
tradition can be envisaged as a long, uninterrupted 'gloss' or series of footnotes to Plato (see Whitehead 1978: 39).

Within the autobiographical account of the Erinnerungen, Jonas assigns a central place to a description of the genesis and development of a range of reflections which were to find their ultimate crystallisation in the publication, in 1987, of Der Gottessbegriff nach Auschwitz. The subtitle to this work, Eine jüdische Stimme, is a reminder not to overlook the intellectual or even 'theological' atmosphere - marked by continuity and discontinuity, bearing all the appropriate distinctions in mind - that always underlies Jonas's position.?

What I wish to do, first of all, is to identify the specificity of Jonas's perspective with respect to the underlying topic I have chosen to focus on, namely his relationship with Plato, based on the lively presentation offered by the German thinker himself. The latter recalls that there is an essential Ur-text, so to speak, which we can refer to in order to understand the structure and meaning of his (provocative) Jewish voice. The latter touches upon the ever-recurrent theme of immortality and, more generally, of the existence and characteristics of God - this being one of the "unavoidable questions" that emerge again and again along Jonas's intellectual trajectory.

In this regard, it may be worth quoting in full a text, or rather a conversation that Jonas deemed "unvergeßlich", in which - as he rarely does in his writing - the German scholar openly professes his faith in God, as though this were a natural consequence of his existential fabric. When invited to Hannah Arendt's home, together with his wife Lore, and "mit Mary McCarhy und einer Freundin von ihr, die in Rom lebte und, wie sich bald herausstellte, gläubige Katholikin war", Jonas was pressed by the latter with a crucial question: “Glauben Sie an Gott?”. While slightly baffled by the lady's direct tone, Jonas apparently gave in and abandoned his aloof, somewhat rigid demeanour as a philosopher and researcher, answering:

Ich sah sie erst etwas ratlos an, dachte nach und sagte - zu meiner eigenen Überraschung: 'Ja!' Hannah zuckte zusammen - ich weiss noch, wie sie mich fast erschrocken ansah. 'Wirklich?' Und ich erwiderte: 'Ja. Letzen Endes ja. Was immer das bedeuten mag, die Antwort 'Ja' kommt der Warheit näher als 'Nein';

7 See Jonas (1987a) and now the critical edition in Jonas (2014: 407-426), from which all the following quotations are drawn; see also here pp. LXII-LXVII. A linear, simple, yet often useful reconstruction of Jonas's specifically Jewish point of view is offered by Troster (2003); the monograph by Baum (2004) makes for more demanding reading; for a critical perspective, see Sommer (1995). For an initial overview of the varied Jewish debate on the question of what comes "after Auschwitz", see also Kajon (1993; esp. on Jonas 65-80); finally, on the reception of Jonas's work more generally, see Fossa (2014: 17-42). 
Some time later, he was equally surprised to hear Arendt herself state, in a frank conversation cutting to the very heart of things: "Ich habe nie an einem personlichen Gott gezweifelt" (Jonas 2003: 341).

4. To return to our Ur-text, this is a lecture intended to discuss the unavoidable and dominant uncertainty surrounding the issue of divine immortality. Included in the cycle of Ingersoll Lectures published in 1961, this lecture was delivered as part of an event featuring contributions by other leading figures. ${ }^{8}$ It was later published with the title Immortality and Modern Temper. ${ }^{9}$ Aside from all the details and specific doctrines that in my view are, at least implicitly, entailed by Jonas's approach, what he explicitly traces back to Plato is the adoption of a particular mode of communication or - if we wish to keep to Jonas's own words - of a genuine "Mittel der Reflexion und Aussprache", namely: myth, by which, he adds, "war mir die Möglichkeit, eine nicht unmittelbar auszusagende Wahrheit letztlich doch auszusprechen, vertraut geworden," according to a choice already adopted (aggressively, in a way) within the context of the Gnostic myth, which was far from foreign to Jonas's early historical-religious interests. ${ }^{10}$

With regard to this choice and its significance within the later compositional structure of Der Gottesbegriff nach Auschwitz, it is worth putting forward a series of considerations, which can be strengthened and integrated by also briefly recalling Jonas's wider perspective on the 'thought of God'. It is worth recalling that the short yet very dense text in question ought to be read not only on the level of philosophical reflection, but also - and especially - against the backdrop of the tragedy of the Shoah, a terrible event experienced by the Jewish people as a whole, and one which had left a permanent mark on Jonas's life, insofar as his mother had died at Auschwitz. The author powerfully declares his underlying aim at the very beginning: the text more or less proudly aims to provide "ein Stück unverhüllt spekulativer Theologie" (Jonas 2014: 407). This is a far from easy task, but it must largely be viewed against the background of Jonas's unflagging interest in the divine and in the question of creation. It is not a fleeting divertissement, but the outcome of an operation motivated by a sort of extreme intellectual effort. Jonas does not let himself be blinded by any form of hermeneutical hybris or heuristic furor: he does not claim to be having the final word on the mystery of God. In this sense, I believe

\footnotetext{
${ }^{8}$ Among these, Jonas recalls Tillich and Whitehead, as though to proudly establish himself in the footsteps of prominent thinkers, albeit very diverse ones in terms of their intellectual approach and style: see Jonas (2003: 342).

9 See Jonas (1962) and, for the German version, Jonas (1963), now in Jonas (2014: 341-366). For a 'stratigraphical' reconstruction of the genesis and composition of the idea put forward in texts ranging from this contribution to the final version of Der Gottessbegriff nach Auschwitz, see Jonas (1987b; esp. 1, n. 1); see also Jonas (2014: 528-530). (2003).

${ }^{10}$ Both quotations in Jonas (2003: 342). On the communicative power of Jonas's myth, see also Frogneux
} 
it is enough to recall a pithy statement from the concluding section of Der Gottesbegriff nach Auschwitz, which unquestionably shows the cautiousness, modesty, and conscious self-limitation that Jonas imposes on his speculations, or rather suppositions, about God:

Meine Damen und Herren! All dies ist Gestammel. Selbst die Worte der grossen Seher und Beter, der Propheten und Psalmisten, die ausser Vergleich stehen, waren ein Stammeln vor dem ewigen Geheimnis. Auch jede Antwort auf die Hiobsfrage kann nicht mehr als das sein (Jonas 2014: 425).

5. In Jonas's eyes, one of the greatest difficulties in any anachronistically strong attempt to thematically address the question of God lies in the kind of approach and form of expression one chooses to adopt. Aware of the risks involved, Jonas does not develop a 'treatise' expounding a new theology; he does not present a succession of propositions about the divine and its relationship with the world that are more or less demonstrated more geometrico. As already noted, in order to buttress his way of thinking about God (even from a rhetorical perspective), he resorts to a myth. ${ }^{11}$ At this point, and with this clear aim in view, in a very free and - I would say - original way, he turns both to the Classical Greek heritage (the Platonic heritage, and particularly the figure of the Demiurge from the Timaeus) and to the tradition of a certain strand of Jewish mysticism, that of Isaac Luria. The latter is filtered - and possibly radicalised - through a complex yet far from passive relationship with Scholem and his reinterpretation of peculiar Jewish currents. ${ }^{12}$

This is not the place to delve into the details of this Jewish source of inspiration or into the minute aspects of the texts and the many nuances of Jonas's construction of a myth. I only wish to point out that his use of a mythical apparatus does not at all coincide with the foregoing of reason or, worse still, with a yielding to irrationalism. Rather, just as with Plato (who once again proves to be an unavoidable point of reference for Jonas, including for the more generally methodological framing of his philosophical research), it coincides with the conscious choice to adopt a different communicative register, which must nonetheless be acknowledged to possess all the power and lucidity of a philosophy about God. In any case, it must not be assumed that this attempt is designed to become a strong form of knowledge stricto sensu; rather, it appears to be conceived as a kind of "spekulative Theologie", ${ }^{13}$ or at any rate as a faltering theological hypothesis. Through a radical rethinking of the very concept of “'Erinnerung', die das Partikulare und Individeuelle (worauf es hier ankommt) bewahrt", without any need to invoke "Platons 'überhimmlischer Ort' der eiwigen Formen”, "Plotins 'intelligibler Kosmos' der ewigen Wahrheiten” and "Hegels 'absoluter Geist", this hypothesis can even give rise to "unser theologisches Postulat",

\footnotetext{
${ }^{11}$ On Jonas and his use of myths see at least Bonaldi (2007); Borghese Keene (2014) is also useful.

12 See esp. Scholem (1941); for a broader perspective on Jonas's intellectual relationship and friendship with Scholem (and Arendt), touching upon Zionism and the tragedy of the Holocaust, see Wiese (2008).

13 For some useful observations see Jonas (2014: XXIV, LI-LXXI).
} 
connected to "eine Subjektivität, die das konkret Tatsächliche, wie es sich begibt, erlbet und ihrem wachsenden Gedächtnis einverliebt. Also ein in dieser Hinsicht werdender, wenngleich ewig existierender Geist" ${ }^{14}$

As far as historico-philosophical indebtedness is concerned, we may add that Jonas plausibly draws upon Kant and the unambiguous pages of his Critique of Pure Reason devoted to Transcendental Dialectic - pages directed against any claim to be able to 'demonstrate' (beweisen) God's existence a priori, as opposed to simply postulating it and endorsing a kind of acceptance and existential disposition. At the same time, however, unlike - and perhaps beyond - Kant, Jonas does not endorse the idea of a kind of faith rationally anchored in practical reason and in the archetype of the moral law. ${ }^{15}$

6. These possible or hypothetical historico-philosophical links aside, it is worth quoting Jonas's words directly, to illustrate the reasons for his choice to resort to the peculiar and indeed unique device of myth:

damals half ich mir mit einer selbsterdachten Mythos - jenem Mittel bildlicher, doch glaublicher Vermutung das Plato für die Sphere jenseits des Wißbaren erlaubte (...). Im Anfang, aus unerkennbarer Wahl, entschied der göttliche Grund des Seins, sich dem Zufall, dem Wagnis und der endlosen Mannigfaltigkeit des Werdens anheimzugeben. Und zwar gänzlich: Da sie einging in das Abenteuer von Raum und Zeit, hielt die Gottheit nichts von sich zurück; kein unergriffener und immuner Teil von ihr blieb, um die umwegige Ausformung ihres Schicksals in der Schöpfung von jenseits her zu lenken, zu berichtigen und letztlich zu garantieren (Jonas 2014: 410).

First of all, a few preliminary remarks can be made, in order to avoid possible misunderstandings.

Firstly, for Jonas such a God in any case remains the creator of the world of becoming. In Das Prinzip Verantwortung he emphatically states: "daß er [scil.: Gott] sie [scil.: die Welt] gewollt habe, und zwar als etwas 'Gutes' (siehe zum Beispiel Genesis und Platon's Timaeus)"; and one has to add, "daß er sie wollte, weil ihre Existenz gut ist, nicht dass diese gut ist, weil er sie wollte (obwohl letzteres die bestürzende Ansicht des Duns Scotus war)". ${ }^{16}$

Secondly, despite this creationist equating of the biblical tradition and Plato's writing, the God evoked by the myth of Der Gottesbegriffnach Auschwitz proves distant from the Platonic Demiurge - and not merely because he does not create things absolutely ex nihilo. As Jonas himself had already emphasised, when analysing precisely the Jewish-Chris-

\footnotetext{
${ }_{14}$ The last quotations are from Vergangenheit und Wahrheit. Ein spater Nachtrag zu den sogenannten Gottesbeweisen, now in Jonas (2014: 456).

15 Besides the lucid reconstruction in Theis (2008), see also Gens (2013).

16 Both quotations are from Jonas (2015: 104). On Plato's “essentialism” see also Jonas's lucid observations in his Wandel und Bestand. Vom Grunde der Verstehbarkeit des Geschichtlichen, now in Jonas (2014: 292-294).
} 
tian-Muslim concept of creation out of nothing: "the opening sentences of Genesis almost suggest a primordial, chaotic matter as preceding the work of creation, or could easily be construed in that sense; and Plato's Timaeus, so highly esteemed in the Middle Ages, had certainly shown the philosophical compatibility of an external 'receptacle' (the prototype of Aristotelian 'matter') with the concept of a divine creator" (Jonas 1980: 36-37 and 338). Nevertheless, while Jonas's new conception deprives God of the attribute of omnipotence, “vor allem bleibt es bei dem einen Gott und so bei dem 'Höre Israel'; kein manichäischer Dualismus wird bemüht zur Erklärung des Bösen, aus den Herzen der Menschen allein steigt es auf und gewinnt es Macht in der Welt”. Therefore, one must not yield to any, more or less Manichaean, form of radical dualism, but nor can one accept "die platonische Gestalt eines passiven Mediums, das - ebenso universal - die Verkörperung des Ideals in der Welt nur unvollkommen gestattet: eine Form-Stoff-Ontologie"; for "die platonische Wahl beantwortet bestenfalls das Problem der Unvollkommenheit und der Naturnotwendigkeit, aber nicht das des positiv Bösen, das eine Freiheit mit eigener Ermächtigung selbst ihrem Schöpfer gegenüber impliziert". ${ }^{17}$

Finally, Jonas's God would not appear to be involved in any "intelligent design", as may perhaps be said and hypothesised instead with regard to Plato's Demiurge, the real ancient paradigm of this strong teleological approach..$^{18}$

These two observations are certainly sufficient in themselves to lead to a correct understanding of Jonas's relationship with the Greek tradition: his relationship with the classical sources, and particularly Plato, is a very free, personal, almost 'creative' one. It is particularly significant in the case of his reinterpretation of the Timaeus (one of the dialogues he loved and quoted the most, with much delight and eagerness, as already noted), which is explicitly brought into play through the mythological veneer of his metaphysical-theological speculation.

Accordingly, also thanks to the peculiar use of the Platonic heritage attested in Der Gottessbegriff nach Auschwitz, it can safely be argued, I think, that above all stands Plato. Indeed, when pondering whether to assign the palm to Kant or to Plato in his Erinnerungen, Jonas himself admits:

Bei Plato muß man eine viel weiteren Weg zurücklegen, um ihn aktuell verwertbar zu machen. Aber natürlich ist Plato der Großte, der, den man immer wieder neu studieren, entdecken muß, während man sich bei Kant schließlich auskennen kann. Bei Plato kommt man nie zu einem Ende. Das ist die große Grundlegung der westlichen Philosophie (Jonas 2014: 430, n. 12).

17 For the quotations see Jonas (2014: 423).

${ }^{18}$ In this regard, see the strong - almost 'militant' - reinterpretation provided by Sedley (2007: ch. IV). For an understanding of the Timaeus in general and of the figure of the Demiurge in particular, Cornford (1937) remains a 'classic' work; Broadie's interpretation is very stimulating, also with respect to the mythical dimension of the Timaeus (see Broadie (2012), esp. ch. 1, which strongly confirms the clear difference between the Platonic Demiurge and the biblical God, who creates the world ex nihilo). 


\section{BIBLIOGRAPHY}

BAUM, W., 2004, Gott nach Auschwitz: Reflexionen zum Theodizeeproblem im Anscluß an Hans Jonas, Paderborn.

BoNALDI, C., 2007, Hans Jonas e il mito. Tra orizzonte trascendentale di senso e apertura alla trascendenza, Vercelli.

BorgheSe KeENe, E., 2014, Hans Jonas. Mythe, temps et mémoire, Hildeshien-Zürich-New York.

BroAdie, S., 2012, Nature and Divinity in Plato's Timaeus, Cambridge.

Chiaradonna, R., 2017, Il platonismo, Bologna.

CoRnFord, F. M. D., 1937, Plato's Cosmology. The "Timaeus" of Plato translated with a running commentary, London.

Fossa, F., 2014, Il concetto di Dio dopo Auschwitz. Hans Jonas e la gnosi, Pisa.

Frogneux, N., 2003, "La souffrance humaine maximisée en Dieu. Une lecture du mythe de Hans Jonas”, Filosofia 20, pp. 125-140.

GENS, J.-C., 2013, L'assise ontologique et les arrière-plans cosmogoniques de l'éthique jonassienne, in: C. Larrère, É. Pommier (éds.), L'éthique de la vie chez Hans Jonas, Paris, pp. 145-158.

HoвsBawn, E., 1994, The Age of Extremes. The Short Twentieth Century 1914-1991, London.

Jonas, H., 1934, Gnosis und spätantiker Geist, Teil I: Die mythologische Gnosis. Mit einer Einleitung "Zur Geschichte und Methodologie der Forschung”, Göttingen.

JonAs, H., 1962, “Immortality and Modern Temper”, Harvard Theological Review 15, pp. 1-20.

JoNAs, H., 1963, Unsterblichkeit und heutige Existenz, in: H. Jonas, Zwischen Nichts und Ewigkeit. Zur Lehre vom Menschen, Göttingen, pp. 44-62 (also in: Jonas 2014: 341-366).

JoNAs, H., 1966, The Phenomenon of Life. Toward a Philosophical Biology, New York.

JonAs, H., 1979, Das Prinzip Verantwortung. Versuch einer Ethik für die technologische Zivilisation. Frankfurt am Main (also in: Jonas 2015: 1-420).

Jonas, H., 1980, Philosophical Essays. From Ancient Creed to Technological Man, Chicago.

JonAs, H., 1987a, Der Gottesbegriffnach Auschwitz. Eine jüdische Stimme, Frankfurt am Main (also in: Jonas 2014: 407-426).

JoNAs, H., 1987b, “The Concept of God after Auschwitz: A Jewish Voice”, The Journal of Religion 67, pp. 1-13.

JoNAS, H., 2003, Erinnerungen, Frankfurt am Main-Leipzig.

Jonas, H., 2012, Kritische Gesamtausgabe der Werke von Hans Jonas. Philosophische Hauptwerke, Bd. II.2: Ontologische und wissenschaftliche Revolution, J. P. Brune (Hg.), Freiburg i. Br.-Berlin-Wien.

Jonas, H., 2014, Kritische Gesamtausgabe der Werke von Hans Jonas. Philosophische Hauptwerke, Band III.1: Metaphysische und religionsphilosophische Studien, M. Bongardt, U. Lenzig, W. E. Müller (Hgg.), Freiburg i. Br.-Berlin-Wien.

Jonas, H., 2015, Kritische Gesamtausgabe der Werke von Hans Jonas. Philosophische Hauptwerke, Band I.2.1: Das Prinzip Verantwortung, Erster Teilband: Grundlegung, D. Böhler, B. Herrmann (Hgg.), Freiburg i. Br.-Berlin-Wien.

KAJON, I., 1993, Fede ebraica e ateismo dopo Auschwitz, Perugia.

Scholem, G., 1941, Major Trends in Jewish Mysticism, New York.

SEDLEy, D.N., 2007, Creationism and Its Critics in Antiquity, Berkeley-Los Angeles-London.

Sommer, U., 1995, “Gott als Knecht der Geschichte: Hans Jonas' ‘Gottesbegriff nach Auschwitz'. Eine Widerrede", Theologische Zeitschrift 51, pp. 340-356.

SPINelli, E., 2019, Obiettivo Platone: a lezione da Hans Jonas, Pisa. 
Theis, R., 2008, Jonas. Habiter le monde, Paris.

Troster, L., 2003, "Hans Jonas and the Concept of God after the Holocaust", Conservative Judaism 55, pp. $16-25$.

Whitehead, A.N., 1978, Process and Reality. An Essay in Cosmology, New York.

WiESE, C., 2008, Zionism, the Holocaust, and Judaism in a Secular World: New Perspectives on Hans Jonas's Friendship with Gershom Scholem and Hannah Arendt, in: H. Tirosh, Samuelson, C. Wiese (eds.), The Legacy of Hans Jonas. Judaism and the Phenomenon of Life, Leiden, pp. 159-202.

EMIDIO SPINELLI

/ The Sapienza University of Rome, Italy / emidio.spinelli@uniroma1.it

\section{The Question of God and the Quest for God: Hans Jonas, Plato, and Beyond...}

In reconstructing the conceptual universe of Jonas's philosophy, a privileged place can, or indeed must, be reserved for his relationship with the classical heritage. More specifically, a crucial role is played by Plato, especially because, as Jonas strongly underlines, “with Plato (...) you have to go back a much greater distance to make him applicable to the present. But of course Plato is the greater one, the one we have to study again and again from scratch, the one we must discover (...). With Plato, you're never finished, that's the great foundation for all of Western philosophy". In the light of this premise, this article will focus on the highly original use made in Jonas's Der Gottesbegriff nach Auschwitz of the Platonic heritage, associated with the mythical figure of the Demiurge in the Timaeus.

Plato, Hans Jonas, Mythological thought, Theology, Demiurge 